\title{
ANALISIS KEBIJAKAN PERSEDIAAN DENGAN MODEL Q KASUS LOST SALE DI PT GRAND TEXTIL INDUSTRY BANDUNG
}

\author{
Dr. Ir. Agus Purnomo, MT. \\ Prodi D4 Logistik Bisnis Politeknik Pos Indonesia \\ aguspurnomo@poltekpos.ac.id
}

\begin{abstract}
Abstrak
Permintaan kain paris yang terdiri dari bahan baku Benang Pakan 150/D dan Benang Lusi 75/D PT Grand Textil Industry adalah produsen tekstil bersifat probabilistik. Pelanggan tidak bersedia menunggu jika stok barang yang diminta tidak tersedia dan akan beralih ke produsen lainnya sehingga akan terjadi lost sales. Tujuan penelitian ini yaitu menentukan kebijakan persediaan Benang Pakan 150/D dan Benang Lusi 75/D yang optimal dengan permintaan probabilistik dan meminimasi risiko lost sale. Kebijakan persediaan dengan penetapan pemesanan optimal ( $Q^{*}$ ) sebesar $3.137 \mathrm{~kg}$ untuk benang Pakan 150/D dan $2.562 \mathrm{~kg}$ untuk benang Lusi 75/D akan meminimasi total ongkos persediaan tahunan untuk kedua jenis bahan baku ini. Penetapan reorder point yang optimal ( $\left.r^{*}\right)$ yaitu $414 \mathrm{~kg}$ untuk benang Pakan 150/D dan $280 \mathrm{~kg}$ untuk benang Lusi 75/D, akan menjamin bahwa barang akan datang sesuai lead time dan probabilitas kecepatan konsumsi bahan baku, sehingga kekurangan persediaan dapat diminimasi. Penetapan kebijakan safety stock sebesar untuk $37 \mathrm{~kg}$ benang Pakan 150/D dan $238 \mathrm{~kg}$ untuk benang Lusi 75/D berguna untuk mengantisipasi kekurangan persediaan akibat konsumsi bahan baku yang probabilistik.
\end{abstract}

Kata Kunci: optimasi, probabilistik, lost sale, safety stock, reorder point

\section{PENDAHULUAN}

PT Grand Textil Industry adalah produsen tekstil yang memproduksi kain paris (grey putihan). Permintaan kain paris bersifat probabilistik, dan pelanggan (perusahaan garmen) tidak bersedia menunggu produk yang dipesan, jika stok tidak tersedia di perusahaan. Pada kondisi ini, pelanggan akan beralih ke produsen lainnya untuk memenuhi kebutuhan kain paris, sehingga akan terjadi lost sales (kehilangan penjualan) pada PT Grand Textil Industry. Hal ini dapat dipahami karena di daerah Bandung Raya, banyak produsen tekstil yang memproduksi kain paris dengan harga bersaing. Di lain sisi pabrik garmen harus segera memproduksi garmen sesuai dengan tenggang waktu yang dituntut oleh pelanggan mereka. Agar perusahaan tidak lost sales, maka perlu diproduksi kain paris yang sesuai dengan permintaan pelanggan. Dalam hal menjamin ketersediaan bahan baku kain paris yang terdiri dari Benang Pakan 150/D dan Benang Lusi 75/D, maka perlu dianalisis persediaannya yang optimal. Sehubungan permintaan kain paris adalah probabilistik, maka permintaan kedua bahan bakunya juga probabilistik. Dengan demikian tujuan penelitian ini yaitu menentukan kebijakan persediaan Benang Pakan 150/D dan Benang Lusi 75/D yang optimal dengan permintaan probabilistik dan meminimasi risiko lost sale.

Model persediaan yang digunakan dalam penelitian ini yaitu Persediaan Probabilistik (s,Q) dengan kasus Lost
Sales yang diperkenalkan oleh Hadley \& Whitin. Distribusi pemintaan pada model ini adalah Poisson dan waktu tenggang pemesanannya konstan (deterministik) dengan asumsi pesanan yang belum terpenuhi sebanyak satu (Hadley G., Whitin, T.M, 1963).

Model menggunakan prosedur iterasi untuk mengoptimalkan parameter kebijakan persediaan dengan pendekatan perhitungan total biaya tahunan yang mudah serta telah diadopsi oleh berbagai buku literatur (Tersine, 1994; Silver, 1985). Formulasi model dan solusi untuk menyelesaikan persoalan kekurangan persediaan yang diperlakukan secara lost sales. Dalam hal ini pelanggan tidak bersedia menunggu produk yang dipesan sampai dengan produk tersedia dan pelanggan akan mencari produk tersebut ke produsen lainnya (Senator, 2006).

Lebih lanjut Persediaan model Q ditunjukkan dengan jumlah pemesanan tetap untuk setiap kali pemesanan. Model probabilistik digunakan jika diidentifikasi salah satu dari permintaan atau lead time atau keduanya belum diketahui secara pasti. Model persediaan ini digunakan bila persediaan yang dimiliki tidak dapat memenuhi permintaan pelanggan sehingga backorder atau Lost sales. (Dian \& Erika, 2018).

Menurut Agus Purnomo (2010), bahwa perumusan model persediaan probabilistik Q kasus lost sales dapat diadopsi jika konsumen tidak bersedia menunggu produk yang dipesan sampai dengan tersedia di tokol dan konsumen 
akan mencari produk yang dibutuhkan ke toko lainnya. Model ini diimplemantasikan pada supermarket " $H$ " untuk mencari solusi optimal terhadap seringnya terjadi kekurangan persediaan (lost sales) untuk produk fast moving. Perbedaan dengan penelitian Agus Purnomo (2010), bahwa penelitian ini fokus untuk menetapkan kebijakan bahan baku untuk menjamin ketersediaan bahan baku kain paris yang terdiri dari Benang Pakan 150/D dan Benang Lusi 75/D

\section{METODE PENELITIAN}

\subsection{Data Penelitian}

Data yang digunakan untuk penelitian ini, diambil pada periode Januari - Desember 2020 yang terdiri atas :

1) Waktu ancang pemesanan tiap jenis bahan baku.

2) Data jumlah permintaan bahan baku kain masa lalu.

3) Biaya yang diperlukan dalam melakukan pengendalian bahan baku yang meliputi :

a. Ongkos pesan, meliputi semua ongkos yang dikeluarkan untuk memesan/ membeli barang dari pemasok, tetapi tidak termasuk harga barang itu sendiri. Ongkos pesan (Cs) terdiri dari : Biaya pemeriksaan (inspeksi), Biaya pengangkutan ke gudang, Biaya kirim(transportasi), dan Biaya telepon.

b. Ongkos simpan, merupakan biaya yang timbul akibat penyimpanan persediaan, berupa bunga atas modal yang tertanam, Biaya kerusakan bahan baku (benang) dan Biaya keamanan bahan baku (benang)

c. Ongkos kekurangan persediaan, muncul jika terjadi pesanan yang tidak dapat dipenuhi oleh perusahaan. Ongkos ini diukur dari profit yang tidak diperoleh karena tidak dapat memenuhi produk yang diminta konsumen.

d. Ongkos pembelian : ongkos untuk membeli bahan baku (benang).

4) Lead time : lamanya waktu yang dibutuhkan untuk penyiapan bahan oleh supplier dan waktu pengangkutan barang sampai digudang. Adapun dalam penelitian ini lead timenya adalah selama 3 hari. Hal ini dikarenakan susahnya bahan baku kain paris dan para suppliernya berada di Bandung.

\subsection{Pengujian Bentuk Distribusi}

Model persediaan probabilistik memiliki karakteriktik permintaan yang tidak pasti, namun distribusi kemungkinannya dapat diprediksi berdasarkan data historis permintaan. Pengujian distribusi permintaan dilakukan dengan prosedur sebagai berikut:

1) Menentukan hipotesa awal $\left(\mathrm{H}_{0}\right)$ dan hipotesa alternatif $\left(\mathrm{H}_{1}\right)$.

$\mathrm{H}_{0}=$ data berdistribusi normal.

$\mathrm{H}_{1}=$ data tidak berdistribusi normal.
2) Kriteria Penerimaan

$\mathrm{H}_{0}$ diterima jika chi square hitung $\leq$ chi square tabel.

3) Tentukan taraf keberartian $(\alpha)$, dimana ; $\alpha=$ level of significant $(0,05)$

4) Perhitungan Goodness Of Fit Test.

5) Kesimpulan

\subsection{Kebijakan Optimasi Persediaan}

Biaya persediaan total dapat dihitung setelah dihitung biaya-biaya persediaan yang terdiri dari biaya pemesanan, biaya simpan, dan biaya kekurangan persediaan. Formulasi biaya-biaya persediaan Model Q (G. Handley and T.M Within) ini mengikuti distribusi probabilitas permintaan bahan baku kain dengan melakukan pengujian bentuk distribusi

1) Biaya pemesanan/tahun (Ordering Cost):

$\mathrm{Op}=\boldsymbol{A} \frac{\lambda}{Q}$

2) Biaya Simpan/tahun (Holding Cost) :

Os $=H\left[Q / 2+r-\mu_{l}+\eta(r)\right] . .(2.2)$

3) Biaya kekurangan/tahun (Shortage Cost):

$\mathrm{Ok}=\frac{\pi \lambda}{Q \eta(r)}$

4) Ekspektasi kekurangan persediaan selama lead time: $\eta(r)=\left(\mu_{l}-r\right) \Phi\left[\left(r-\mu_{l}\right) / \sigma_{l}\right]+\sigma_{l} \phi\left[\left(r-\mu_{l}\right) / \sigma_{l}\right]$.

$\phi\left[\left(r-\mu_{l}\right) / \sigma_{l}\right]=f(z)=\frac{1}{\sqrt{2 \pi}} e^{-(1 / 2)^{Z}}$

$\Phi\left[\left(r-\mu_{l}\right) / \sigma_{l}\right]=F(r) . .(2.4)$

5) Biaya total (OT) (Total Inventory Cost):

$\left.O T=\frac{A \lambda}{Q}+H\left[Q / 2+r-\mu_{l}\right]+\left(H+\frac{\pi \lambda}{Q}\right) x \eta(r)\right)$

..$(2.5)$

6) Biaya persediaan Pengaman (Safety Stock):

$S=r-\mu_{l}+\boldsymbol{\eta}(\boldsymbol{r}) \ldots(2.6)$

7) Jumlah pemesanan (Order Quantity):

$Q=\sqrt{\frac{2 \lambda(A+\pi \eta(r))}{H}}$.

8) Probabilitas terjadinya kekurangan persediaan:

$$
F(r)=\frac{Q H}{\pi \lambda+Q H}
$$

Penjelasan :

$\mathrm{r}=$ Titik pemesanan kembali (reorder point)

$\mathrm{A}=$ Ongkos per sekali pesan $(\mathrm{Rp} / \mathrm{thn})$

$\mathrm{H}=$ Ongkos simpan per satuan $(\mathrm{Rp} / \mathrm{thn})$

$\mathrm{Q}=$ Jumlah pemesanan $/ \mathrm{thn}(\mathrm{kg} / \mathrm{thn})$

$\mathrm{Q}^{*}=$ Jumlah pemesanan yang optimal $/$ thn $(\mathrm{kg} / \mathrm{thn})$

$\lambda=$ Permintaan bahan baku untuk periode perencanaan/thn $(\mathrm{kg} / \mathrm{thn})$

$\mu=$ Rata-rata permintaan bahan baku selama lead time ( $\mathrm{kg} / \mathrm{thn})$ 
$\pi=$ Biaya kekurangan persediaan $/ \mathrm{kg} / \mathrm{thn}(\mathrm{kg} / \mathrm{thn})$

\subsection{Penentuan jumlah pemesanan (Q) dan titik pemesanan kembali (r) yang optimal}

Prosedur perhitungan $\mathrm{Q}^{*}$ dan $\mathrm{r}^{*}$ yang optimal (Tersine, 1994):

1) Menghitung nilai $Q$ deterministik sebagai nilai awal:

$$
Q=\sqrt{\frac{2 \lambda A}{H}}
$$

2) Menghitung nilai probabilitas terjadinya kekurangan persediaan $F(r)$ dengan mengunakan nilai $Q$ pada langkah 1, selanjutnya dihitung nilai $r$.

3) Menghitung nilai $Q$ yang baru dengan mengunakan nilai $r$ yang diperoleh dari langkah 2 di atas dengan mengunakan rumus pada persamaan (2.7):

$$
Q=\sqrt{\frac{2 \lambda(A+\pi \eta(r))}{H}}
$$

4) Menghitung kembali nilai F (r) sesuai dengan kasus kekurangan persediaan yang digunakan dengan megunakan nilai $Q$ yang diperoleh dari langkah 3 sebagai masukan.

5) Menghitung langkah 3 dan 4 di atas hingga diperoleh nilai $r$ yang optimal. Dimana kriteria $r$ yang optimal didapat jika antara nilai $\mathrm{r}$ hasil perhitungan terakhir dengan nilai $r$ perhitungan sebelumnya tidak memberikan perbedaan yang berarti dalam satuan unit.

6) Berdasarkan nilai $Q^{*}$ dan $r^{*}$ yang telah optimal, maka dilakukan perhitungan nilai total ongkos persediaan dengan menjumlah biaya pemesanan, biaya simpan serta biaya kekurangan sebagai berikut :

$$
\begin{aligned}
\mathrm{OT} & =\mathrm{OP}+\mathrm{OS}+\mathrm{OK} \\
O T & \left.=\frac{A \lambda}{Q}+H\left[Q / 2+r-\mu_{l}\right]+\left(H+\frac{\pi \lambda}{Q}\right) \eta(r)\right)
\end{aligned}
$$

Langkah-langkah untuk menghitung $\mathrm{Q}^{*}$ dan $\mathrm{r}^{*}$ dapat digambarkan dengan flowchart pada gambar 2.1.

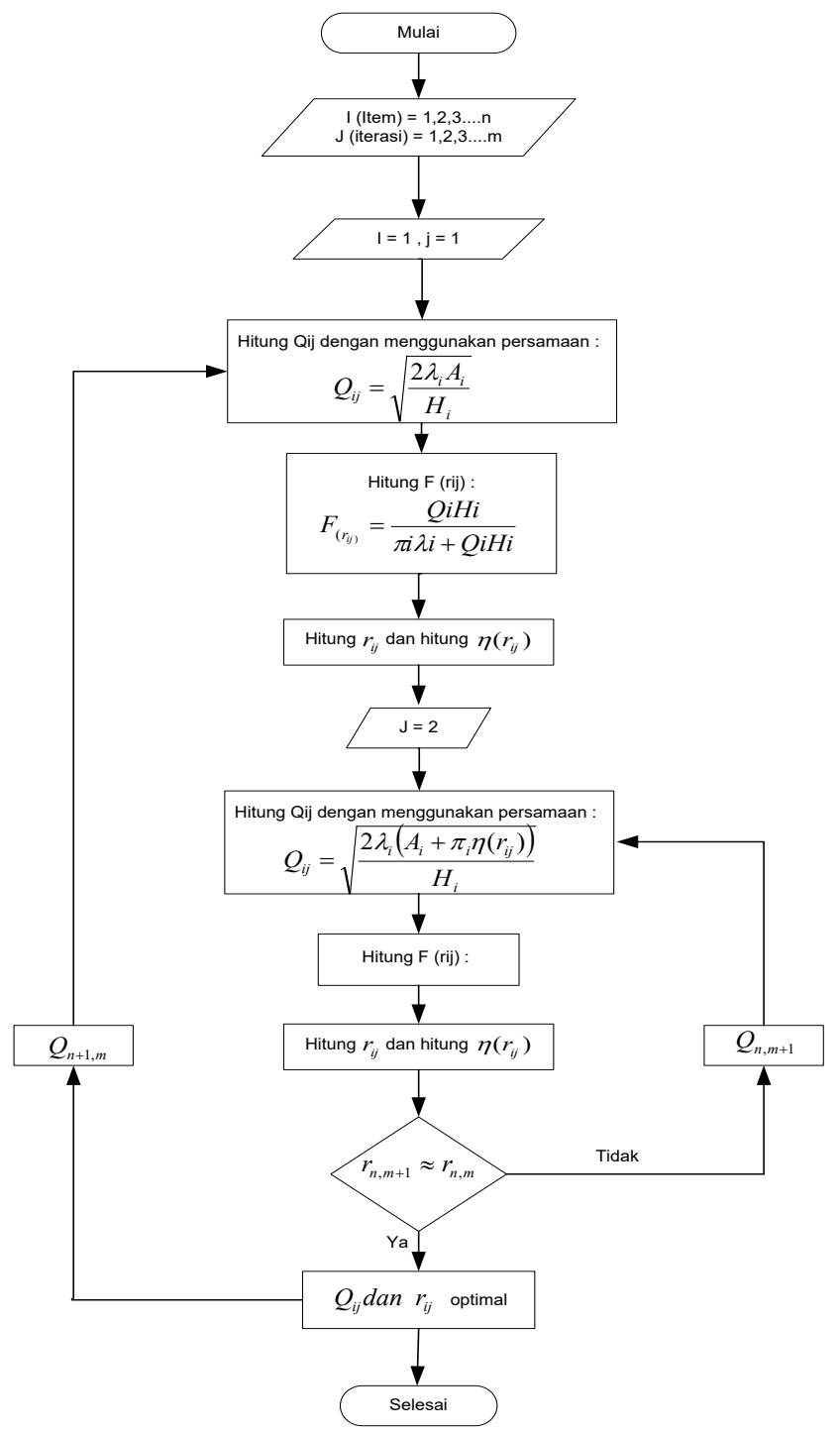

Gambar 1. Diagram alir untuk mencari kebijakan persediaan yang optimal dengan Model Q Probabilistik Kasus Lost Sales

\section{HASIL DAN PEMBAHASAN}

\subsection{Data Demand Bahan Baku}

Komposisi bahan baku kain paris per kg terdiri dari $60 \%$ benang pakan 150/D dan 40\% benang lusi 75/D. Kain paris sepanjang 30 meter, konversi beratnya yaitu $1,40 \mathrm{~kg}$. Berdasarkan konversi ini maka dapat dihitung penggunaan benang pakan 150/D dan benang lusi 75/D setiap bulannya mula periode Januari 2020 sampai dengan Desember 2020, sebagai berikut : 
Tabel 1. Konversi Kebutuhan bahan baku kain paris Januari - Desember 2020

\begin{tabular}{|l|l|c|c|}
\hline \multirow{2}{*}{ No } & \multirow{2}{*}{ Bulan } & \multicolumn{2}{|c|}{ Kebutuhan (Demand $)$} \\
\cline { 3 - 4 } & & B. Pakan $(\mathrm{kg})$ & B. Lusi (kg) \\
\hline 1 & Januari & 3380 & 2253 \\
\hline 2 & Februari & 3647 & 2431 \\
\hline 3 & Maret & 3659 & 2439 \\
\hline 4 & April & 3786 & 2524 \\
\hline 5 & Mei & 3831 & 2554 \\
\hline 6 & Juni & 3849 & 2566 \\
\hline 7 & Juli & 3896 & 2597 \\
\hline 8 & Agustus & 4083 & 2722 \\
\hline 9 & September & 4096 & 2731 \\
\hline 10 & Oktober & 3882 & 2588 \\
\hline 11 & November & 4049 & 2700 \\
\hline 12 & Desember & 3669 & 2446 \\
\hline \multicolumn{2}{|c|}{ Jumlah } & 45827 & 30551 \\
\hline \multicolumn{3}{|c}{} \\
\hline
\end{tabular}

\subsection{Uji Distribusi Demand Bahan Baku}

Pengujian distribusi demand bahan baku dilakukan sebagai berikut :

Item 1 : (Benang Pakan 150/D)

1) Hipotesa :

$\mathrm{H}_{0}=$ data demand berdistribusi normal.

$\mathrm{H}_{1}=$ data demand tidak berdistribusi normal.

2) Kriteria Penerimaan

$\mathrm{H}_{0}$ diterima jika $\chi^{2}$ hit $\leq \chi_{\text {tabel }}^{2}$

3) Taraf keberartian $(\alpha)$, dimana ; $\alpha=0,05$.

4) Perhitungan Goodness Of Fit Test, berdasarkan data demand.

$$
\begin{aligned}
\chi_{\text {hit }}^{2} & =\frac{\sum_{i=1}^{n}\left(F k-e_{i}\right)^{2}}{e_{i}} \\
= & \frac{(1-(1,743))^{2}}{1,743}=1,169
\end{aligned}
$$

5) Chi square tabel $\left(\chi_{\text {tabel }}^{2}\right)=\chi_{(0,05 ; 4)}^{2}=9,488$.

Sehingga : $\chi_{\text {hit }}^{2}<\chi^{2}$ tabel $\rightarrow 1,169<9,488$.

6) Kesimpulan :

Terima $\mathrm{H}_{0}$, artinya data demand berdistribusi normal.

Item 2 : (Benang Lusi 75/D)

1) Hipotesa :

$\mathrm{H}_{0}=$ data demand berdistribusi normal.

$\mathrm{H}_{1}=$ data demand tidak berdistribusi normal.

2) Kriteria Penerimaan

$\mathrm{H}_{0}$ diterima jika $\chi_{\text {hit }}^{2} \leq \chi_{\text {tabel }}^{2}$

3) Tentukan taraf keberartian ( $\alpha$ ), dimana ; $\alpha=0,05$.

4) Perhitungan Goodness Of Fit Test, berdasarkan data demand .

$$
\begin{aligned}
\chi^{2}{ }_{\text {hit }} & =\frac{\sum_{i=1}^{n}\left(F k-e_{i}\right)^{2}}{e_{i}} \\
& =\frac{(1-(2,703))^{2}}{2,703}=2,333
\end{aligned}
$$

5) Chi square tabel $\left(\chi_{\text {tabel }}^{2}\right)=\chi_{(0,05 ; 4)}^{2}=9,488$.

Sehingga : $\chi^{2}$ hit $<\chi^{2}$ tabel $\rightarrow 2,333<9,488$.

6) Kesimpulan :

Terima $\mathrm{H}_{0}$, artinya data demand berdistribusi normal.

3.3. Pehitungan jumlah Pemesanan $\left(Q^{*}\right)$ dan Titik Pemesanan Kembali $\left(r^{*}\right)$ yang Optimal

3.3.1. Benang Pakan 150/D

Diketahui :

Standar Deviasi $(\sigma)=193 \mathrm{Kg}$

Kebutuhan Benang Pakan Per tahun $(\lambda)=45827 \mathrm{Kg}$

Ongkos Sekali Pesan $(A)=$ Rp. 176.500,00/ sekali pesan

Ongkos Simpan $(\mathrm{H})=$ Rp. $1650 / \mathrm{Kg}$ per tahun

Ongkos Kekurangan Persediaan $(\Pi)=$ Rp. 6000,00

Waktu Ancang (Lead Time) $=3$ hari

Jumlah bulan Dalam Setahun $=12$ Bulan $=365$ hari

Solusi :

Pemakaian selama lead time $\left(\mu_{l}\right)=\left(\frac{L}{T}\right) \times \lambda=$

$$
\frac{3}{365} x 45827 \mathrm{~kg}=376,66 \mathrm{~kg} / \mathrm{th}
$$

Standar deviasi selama lead time $\left(\sigma_{l}\right)=\sigma \times \sqrt{\frac{\mathrm{L}}{\mathrm{T}}}=$

$$
=193 \mathrm{kgx} \sqrt{\frac{3}{365}}=17,497 \mathrm{Kg} / \text { th }
$$

Iterasi I

- Tahap 1

Perkiraan awal jumlah barang yang di pesan

Nilai awal $Q_{i j}=\sqrt{\frac{2 \lambda_{i} A_{i}}{H_{i}}}=$

$$
\sqrt{\frac{2 \times 45827 \times 176500}{1650}}=3131,17 \approx 3131 \mathrm{~kg}
$$

- $\quad$ Tahap 2

Probabilitas kekurangan persediaan selama lead time

$$
\begin{aligned}
F\left(r_{i, j}\right) & =\frac{Q_{i} H_{i}}{\pi_{i} \lambda_{i}+Q_{i} H_{i}} \\
= & \frac{3131 \times 1650}{(6000 \times 45827)+(3131 \times 1650)}=0,01844 \mathrm{~kg}
\end{aligned}
$$

$$
F\left(r_{1,1}\right)=1-\mathrm{F}(\mathrm{z})=\Phi\left(\frac{\mathrm{r}-\mu_{1}}{\sigma_{1}}\right)=0.01844 \mathrm{~kg}
$$


$F\left(r_{1,1}\right)=0,01844 \rightarrow \mathrm{Z}_{\mathrm{tab}}=2,086$

- $\quad$ Tahap 3

Mencari harga $r$ dengan menurunkan persamaan OT (ongkos total) terhadap $r$

Maka r:

$$
\begin{aligned}
r_{i, j} & =\mu_{L}+Z_{L} \sigma_{L} \\
r_{1, l} & =376,66 \mathrm{~kg}+((2,086) \times 17,497 \mathrm{~kg}) \\
& =413,1594 \mathrm{~kg}
\end{aligned}
$$

- $\quad$ Tahap 4

Menghitung ekspektasi kekurangan persediaan selama lead time

$\stackrel{\eta}{=}\left(\mu_{l}-r\right) \Phi\left[\left(r-\mu_{l}\right) / \sigma_{l}\right]+\sigma_{l} \phi\left[\left(r-\mu_{l}\right) /{ }^{(r i, j)}\right]$

- Untuk mencari ordinat kurva dibawah distribusi normal :

$$
\begin{array}{r}
\phi\left[\left(r-\mu_{l}\right) / \sigma_{l}\right]=f(z)=\left(\frac{1}{\sqrt{2 \pi}}\right) e^{-\frac{Z^{2}}{2}} \\
=\left(\frac{1}{\sqrt{2 * 3,14}}\right) 2,72^{-\frac{2,086^{2}}{2}}=0,0452
\end{array}
$$

- Probabilitas kekurangan persediaan $\Phi\left[\left(r-\mu_{l}\right) / \sigma_{l}\right]=F(r)=0.01844$

Maka $\eta(r)$ :

$\eta\left(r_{11}\right)=((376,66-413,16) \times(0,01844))+(17,497$ $\mathrm{x} 0.0452)=0,1178 \mathrm{~kg}$

Iterasi II

- Tahap 5

Mencari harga $Q_{2}$ dengan menurunkan persamaan OT (ongkos total) terhadap Q

$$
Q_{i, j}=\sqrt{\frac{2 \lambda_{i}\left(A_{i}+\pi_{i} \eta\left(r_{11}\right)\right)}{H_{i}}}
$$

$Q_{1,2}=$

$$
\sqrt{\frac{2 x 45827 x(176500+(6000 x 0,1178)}{1650}}=3137,429 \mathrm{~kg}
$$

- $\quad$ Tahap 6

Probabilitas kekurangan persediaan selama lead time

$$
\begin{aligned}
& F\left(r_{i, j}\right)=\frac{Q_{i} H_{i}}{\pi_{i} \lambda_{i}+Q_{i} H_{i}} \\
& = \\
& \frac{3137,429 \times 1650}{(6000 \times 45827)+(3137,429 \times 1650)}=0,018479 \mathrm{~kg}
\end{aligned}
$$$$
F\left(r_{1,2}\right)=1-\mathrm{F}(\mathrm{z})=\Phi\left(\frac{\mathrm{r}-\mu_{1}}{\sigma_{1}}\right)=0,018479 \mathrm{~kg}
$$$$
F\left(r_{1,2}\right)=0,01847 \rightarrow \mathrm{Z}_{\mathrm{tab}}=2,084
$$

\section{- $\quad$ Tahap 7}

Mencari harga $r$ dengan menurunkan persamaan OT (ongkos total) terhadap $r$

Maka r:

$$
\begin{aligned}
r_{1,2} & =\mu_{L}+Z_{L} \sigma_{L} \\
& =376,66 \mathrm{~kg}+((2,084) \times 17,497 \mathrm{~kg}) \\
& =413,1237 \mathrm{~kg}
\end{aligned}
$$

Karena r1 dan r2 mempunyai perbedaan relatif kecil maka iterasi dehentikan pada iterasi ke 2 dengan Q2 yaitu $3137,429 \approx 3137 \mathrm{~kg}$ dan reorder point sebesar 413,1237 $\approx 413 \mathrm{~kg}$

* Frekuensi Pemesanan $=\frac{\lambda}{Q^{*}}$

$=\frac{45827}{3137}=14,61 \approx 15$ kali pemesanan

* Persediaan pengaman (S)

$$
\begin{aligned}
S & =r-\mu_{l}+\boldsymbol{\eta}(\boldsymbol{r}) \\
& =413 \mathrm{~kg}-376,66 \mathrm{~kg}+0,1178 \mathrm{~kg} \\
& =36,222 \mathrm{~kg}=37 \mathrm{~kg}
\end{aligned}
$$

Biaya pemesanan/tahun (Ordering Cost):

$$
\begin{aligned}
\text { Op } & =\boldsymbol{A} \frac{\lambda}{Q} \\
& =\frac{176.500 \times 45827}{3137}=\operatorname{Rp} 2.578 .407,874 / \text { th }
\end{aligned}
$$

- Biaya Simpan/tahun (Holding Cost) :

$$
\begin{aligned}
\text { Os } & =H\left[Q / 2+r-\mu_{l}+\eta(r)\right] \\
& =1650 x\left[\frac{3137}{2}+413-376,66+0.1178\right] \\
& =\operatorname{Rp} 2.648 .180 / \text { th }
\end{aligned}
$$

Biaya kekurangan/tahun (Shortage Cost) :

$$
\begin{aligned}
\mathrm{Ok} & =\frac{\pi \lambda \eta(r)}{Q} \\
& =\frac{6000 \times 45827 \times 0,1178}{3137}=\operatorname{Rp} 10325,318 / \text { th }
\end{aligned}
$$

* Ongkos total persediaan

$$
\begin{aligned}
\mathrm{OT} & =\mathrm{OP}+\mathrm{OS}+\mathrm{OK} \\
O T & =\frac{A \lambda}{Q}+H\left[Q / 2+r-\mu_{l}+\eta(r)\right]+\frac{\pi \lambda}{Q} \eta(r) \\
& =\operatorname{Rp} 2.578 .407,874+2.648 .180+10.325,318 \\
& =\operatorname{Rp} 5.236 .914 / \mathrm{th}
\end{aligned}
$$

- Kesimpulan

\begin{tabular}{|c|c|c|c|c|}
\hline $\begin{array}{c}\text { Jumlah } \\
\text { Iterasi }\end{array}$ & $\mathrm{Q}$ & $\mathrm{R}$ & $\eta(r)$ & $\mathrm{f}$ \\
\hline 1 & 3131 & 413,1594 & 0,1178 & 14,61 \\
\hline 2 & 3137 & 413,1237 & 0,1178 & 14,61 \\
\hline
\end{tabular}


Dari hasil perhitungan di atas, maka sistem persediaan optimal untuk Benang Pakan 150/D adalah sbb. :

* Jumlah pemesanan tetap (Qo*) $=3137 \mathrm{~kg}$

* Titik pemesanan kembali (r) $=414 \mathrm{~kg}$

* Persediaan pengaman (ss) $\quad=37 \mathrm{~kg}$

* Ongkos total persediaan (OT) = Rp 5. 236.914 /tahun

* Frekwensi pemesanan = 15 kali pesan

\subsubsection{Benang Lusi 75/D}

Diketahui :

Standar Deviasi $(\sigma)=157,6 \mathrm{Kg}$

Kebutuhan Benang Lusi Per tahun $(\lambda)=30551 \mathrm{Kg}$

Ongkos Sekali Pesan (A) = Rp. 176.500/ sekali pesan

Ongkos Simpan $(\mathrm{H})=$ Rp. $1650 / \mathrm{Kg}$ per tahun

Ongkos Kekurangan Persediaan $(\Pi)=$ Rp. 6000,00

Waktu Ancang $($ Lead Time $)=3$ hari

Jumlah bulan Dalam Setahun $=12$ Bulan $=365$ hari

Solusi :

Pemakaian selama lead time $\left(\mu_{l}\right)=\left(\frac{L}{T}\right) \times \lambda=$

$$
=
$$

\section{$\frac{3}{365} \times 30551 \mathrm{~kg}=251,104 \mathrm{~kg} / \mathrm{th}$}

Standar deviasi selama lead time $\left(\sigma_{l}\right)=\sigma \times \sqrt{\frac{\mathrm{L}}{\mathrm{T}}}=$

$$
=157,6 \mathrm{kgx} \sqrt{\frac{3}{365}}=14,288 \mathrm{~kg} / \mathrm{th}
$$

$\underline{\text { Iterasi I }}$

- Tahap 1

Perkiraan awal jumlah barang yang di pesan

Nilai awal $Q_{i j}=\sqrt{\frac{2 \lambda_{i} A_{i}}{H_{i}}}=$

$Q_{1,1}=\sqrt{\frac{2 \times 30551 \times 176500}{1650}}=2556,57 \approx 2557 \mathrm{~kg}$

- Tahap 2

Probabilitas kekurangan persediaan selama lead time

$$
\begin{aligned}
& F\left(r_{i, j}\right)= \frac{Q_{i} H_{i}}{\pi_{i} \lambda_{i}+Q_{i} H_{i}} \\
&= 2556,57 \times 1650 \\
& \frac{(6000 \times 30551)+(2556,57 \times 1650)}{(6)}=0,0225 \mathrm{Kg}
\end{aligned}
$$$$
F\left(r_{1,1}\right)=1-\mathrm{F}(\mathrm{z})=\Phi\left(\frac{\mathrm{r}-\mu_{1}}{\sigma_{1}}\right)=0.0225 \mathrm{~kg}
$$$$
F\left(r_{1,1}\right)=0,0225 \rightarrow Z_{\mathrm{tab}}=2,003
$$

- $\quad$ Tahap 3

Mencari harga $r$ dengan menurunkan persamaan OT (ongkos total) terhadap r
Maka r :

$$
\begin{aligned}
r_{l, j} & =\mu_{L}+Z_{L} \sigma_{L} \\
r_{l, 1} & =251,104 \mathrm{~kg}+(2,003 \times 14,288 \mathrm{~kg}) \\
& =279,723 \mathrm{~kg}
\end{aligned}
$$

- $\quad$ Tahap 4

Menghitung ekspektasi kekurangan persediaan selama lead time

$\stackrel{\eta}{=}\left(\mu_{l}-r\right) \Phi\left[\left(r-\mu_{l}\right) / \sigma_{l}\right]+\sigma_{l} \phi\left[\left(r-\mu_{l}\right) / \sigma_{l}^{(r i, j)}\right]$

- Untuk mencari ordinat kurva dibawah distribusi normal :

$$
\begin{aligned}
& \phi\left[\left(r-\mu_{l}\right) / \sigma_{l}\right]=f(z)=\left(\frac{1}{\sqrt{2 \pi}}\right) e^{-\frac{Z^{2}}{2}} \\
& =\left(\frac{1}{\sqrt{2 * 3,14}}\right) 2,72^{-\frac{2,003^{2}}{2}}=0,0536
\end{aligned}
$$

- Probabilitas kekurangan persediaan $\Phi\left[\left(r-\mu_{l}\right) / \sigma_{l}\right]=F(r)=0.02257 \mathrm{~kg}$

Maka $\eta(r)$ :

$\eta\left(r_{11}\right)=((251,104 \mathrm{~kg}-279,723 \mathrm{~kg}) \times(0,02257))+$ $(14,228 \mathrm{~kg} \mathrm{x} 0,054)=0,117 \mathrm{~kg}$

Iterasi II

- $\quad$ Tahap 5

Mencari harga $Q_{2}$ dengan menurunkan persamaan OT (ongkos total) terhadap Q

$Q_{i, j}=\sqrt{\frac{2 \lambda_{i}\left(A_{i}+\pi_{i} \eta\left(r_{11}\right)\right)}{H_{i}}}$

$Q_{1,2}=$

$$
\sqrt{\frac{2 \times 30551 \times(176500+(6000 x 0,117)}{1650}}=2561,651 \mathrm{~kg} \approx 2562 \mathrm{~kg}
$$

- Tahap 6

Probabilitas kekurangan persediaan selama lead time

$F\left(r_{i, j}\right)=\frac{Q_{i} H_{i}}{\pi_{i} \lambda_{i}+Q_{i} H_{i}}$

$$
=\frac{2562 \times 1650}{(6000 \times 30551)+(2600 \times 1650)}=0,022 \mathrm{~kg}
$$

$F\left(r_{l, 2}\right)=1-\mathrm{F}(\mathrm{z})=\Phi\left(\frac{\mathrm{r}-\mu_{1}}{\sigma_{1}}\right)=0.022 \mathrm{~kg}$

$F\left(r_{l, 2}\right)=0,022 \rightarrow \mathrm{Z}_{\mathrm{tab}}=2,003$

- $\quad$ Tahap 7

Mencari harga $r$ dengan menurunkan persamaan OT (ongkos total) terhadap $\mathrm{r}$

Maka $r$ :

$$
\begin{aligned}
r_{l, 2} & =\mu_{L}+Z_{L} \sigma_{L} \\
& =251,104 \mathrm{~kg}+(2,003 \times 14,288 \mathrm{~kg}) \\
& =279,723 \mathrm{~kg}
\end{aligned}
$$

Karena r1 dan r2 mempunyai perbedaan relatif kecil maka iterasi dihentikan pada iterasi ke 2 dengan Q2 yaitu 
$2561,651 \mathrm{~kg} \approx 2562 \mathrm{~kg}$ dan reorder point sebesar 279,723 $\approx 280 \mathrm{~kg}$

* Frekuensi Pemesanan $=\frac{\lambda}{Q^{*}}$

$=\frac{30551}{2562}=11,92 \approx 12$ kali pemesanan

* Persediaan pengaman (S)

$$
\begin{aligned}
S & =r-\mu_{l}+\boldsymbol{\eta}(\boldsymbol{r}) \\
& =489 \mathrm{~kg}-251,104 \mathrm{~kg}+0,117 \mathrm{~kg} \\
& =237,779 \mathrm{~kg} \approx 238 \mathrm{~kg}
\end{aligned}
$$

* Biaya pemesanan/tahun (Ordering Cost):

$$
\begin{aligned}
\mathrm{Op} & =\boldsymbol{A} \frac{\lambda}{\boldsymbol{Q}} \\
& =\frac{176500 \times 30551}{2562}=\operatorname{Rp~} 2.104 .703,94 / \text { th }
\end{aligned}
$$

* Biaya Simpan/tahun (Holding Cost) :

$$
\begin{aligned}
\mathrm{Os} & =H\left[Q / 2+r-\mu_{l}+\eta(r)\right] \\
& =1650 x\left[\frac{2562}{2}+489-251,104+0,117\right] \\
& =\operatorname{Rp} 2.506 .371,45 / \text { th }
\end{aligned}
$$

- Biaya kekurangan/tahun (Shortage Cost) :

$$
\begin{aligned}
\mathrm{Ok} & =\frac{\pi \lambda \eta(r)}{Q} \\
& =\frac{6000 \times 30551 \times 0,117}{2562}=\operatorname{Rp} 8371,117 / \mathrm{th}
\end{aligned}
$$

* Ongkos total persediaan

$\mathrm{OT}=\mathrm{OP}+\mathrm{OS}+\mathrm{OK}$

$O T=\frac{A \lambda}{Q}+H\left[Q / 2+r-\mu_{l}+\eta(r)\right]+\frac{\pi \lambda}{Q} \eta(r)$

$=\operatorname{Rp} 2.104 .703,94+\operatorname{Rp} 2.506 .371,45+\operatorname{Rp} 8371,117$

$=\operatorname{Rp} 4.619 .447 / \mathrm{th}$

- Kesimpulan

\begin{tabular}{|c|c|c|c|c|}
\hline $\begin{array}{c}\text { Jumlah } \\
\text { Iterasi }\end{array}$ & $\mathrm{Q}$ & $\mathrm{R}$ & $\eta(r)$ & $\mathrm{f}$ \\
\hline 1 & 2557 & 280 & 0,117 & 11,92 \\
\hline 2 & 2562 & 280 & 0,117 & 11,92 \\
\hline
\end{tabular}

Dari hasil perhitungan di atas, maka sistem persediaan optimal untuk Benang Lusi 75/D adalah sebagai berikut :

$$
\begin{array}{lll}
\text { Jumlah pemesanan tetap }\left(\mathrm{Qo}^{*}\right) & =2562 \mathrm{~kg} \\
\text { Titik pemesanan kembali (r) } & =280 \mathrm{~kg} \\
\text { Persediaan pengaman }(\mathrm{ss}) & =238 \mathrm{~kg} \\
\text { Ongkos total persediaan (OT) } & =\mathrm{Rp} 4.619 .447 / \mathrm{th} \\
\text { Frekwensi pemesanan } & =12 \mathrm{kali} \text { pesan }
\end{array}
$$

Berdasarkan hasil perhitungan di atas maka dapat direkap parameter kebijakan persediaan yang optimal pada tabel 2 .
Tabel 2. Hasil Perhitungan Metode Q Probabilistik kasus Lost Sales

\begin{tabular}{l|c|c|}
\multirow{2}{*}{ Kebijakan Persediaan } & \multicolumn{2}{|c|}{ Jenis Bahan Baku Benang } \\
\cline { 2 - 3 } & Pakan 150/D & Lusi 75/D \\
\hline $\mathrm{Q}^{*}(\mathrm{Kg})$ & 3.137 & 2.562 \\
\hline $\mathrm{r}^{*}(\mathrm{Kg})$ & 414 & 280 \\
\hline $\mathrm{ss}(\mathrm{Kg})$ & 37 & 238 \\
\hline Kebutuhan pertahun (Kg) & 45.827 & 30.551 \\
\hline Frekuensi pemesanan & 15 & 12 \\
\hline Ongkos pesan/ tahun (Rp) & $2.578 .407,87$ & $2.104 .703,94$ \\
\hline Ongkos simpan/ tahun & 2.648 .180 & $2.506 .371,45$ \\
\hline $\begin{array}{l}\text { Ongkos kekurangan } \\
\text { persediaan/ tahun (Rp) }\end{array}$ & $10.325,32$ & $8.371,12$ \\
\hline $\begin{array}{l}\text { Ongkos total persediaan/ } \\
\text { tahun (Rp) }\end{array}$ & 5.236 .914 & 4.619 .447 \\
\hline $\begin{array}{l}\text { Lead time (hari) } \\
\text { Kebutuhan selama lead } \\
\text { time (Kg) }\end{array}$ & 3 & 3 \\
\hline $\begin{array}{l}\text { Standar deviasi selama } \\
\text { lead time(Kg) }\end{array}$ & 17,497 & 14,288 \\
\hline
\end{tabular}

Berdasarkan perhitungan di atas dan parameter kebijakan persediaan yang optimal pada tabel 2, bahwa kekurangan persediaan bahan baku benang selama lead time relatif kecil, hal ini dicerminkan oleh ongkos kekurangan persediaan tahunan yang relatif kecil pula. Penentuan titik pemesanan kembali/ reorder point yang optimal ( $\left.\mathrm{r}^{*}\right)$ yaitu $414 \mathrm{~kg}$ untuk benang Pakan 150/D dan $280 \mathrm{~kg}$ untuk benang Lusi 75/D, akan menjamin bahwa barang akan datang sesuai lead time dan probabilitas kecepatan konsumsi bahan baku, sehingga kekurangan persediaan dapat diminimasi. Disisi lainnya dalam hal mengantisipasi kekurangan persediaan maka ditetapkan kebijakan safety stock (persediaan pengaman) sebesar untuk $37 \mathrm{~kg}$ benang Pakan 150/D dan $238 \mathrm{~kg}$ untuk benang Lusi 75/D. Selain itu jumlah pemesanan optimal $\left(\mathrm{Q}^{*}\right)$ untuk benang Pakan 150/D sebesar $3.137 \mathrm{~kg}$ dan untuk benang Lusi 75/D sebesar $2.562 \mathrm{~kg}$ mendukung untuk memproleh ongkos persediaan total bahan baku yang optimal yaitu sebesar Rp. 5.236.914,- untuk benang Pakan 150/D dan 4.619.447 benang Lusi 75/D, dimana ongkos total ini tidak termasuk harga pembeliaan (item/purchase cost).

\section{KESIMPULAN}

Kesimpulan penelitain ini adalah sebagai berikut :

1. Kebijakan persediaan dengan penetapan pemesanan optimal (Q*) sebesar $3.137 \mathrm{~kg}$ untuk benang Pakan 150/D dan $2.562 \mathrm{~kg}$ untuk benang Lusi 75/D akan meminimasi total ongkos persediaan tahunan untuk kedua jenis bahan baku ini.

2. Penetapan reorder point yang optimal ( $\left.\mathrm{r}^{*}\right)$ yaitu 414 $\mathrm{kg}$ untuk benang Pakan 150/D dan $280 \mathrm{~kg}$ untuk benang Lusi 75/D, akan menjamin bahwa barang akan datang sesuai lead time dan probabilitas kecepatan 
konsumsi bahan baku, sehingga kekurangan persediaan dapat diminimasi.

3. Penetapan kebijakan safety stock sebesar untuk $37 \mathrm{~kg}$ benang Pakan 150/D dan $238 \mathrm{~kg}$ untuk benang Lusi 75/D berguna untuk mengantisipasi kekurangan persediaan akibat konsumsi bahan baku yang probabilistik.

\section{REFERENSI}

[1] Agus Purnomo. Perencanaan Inventori Model Probabilistik Q Kasus Lost Sales Di Supermarket " $H$ " Bandung. Prosiding Seminar Nasional IV Manajemen dan Rekayasa Kualitas: Membudayakan Standar dan Rekayasa Kualitas untuk Memperkuat Daya Saing lndustri. Bandung. 2010. Jurusan Teknik Industri ITENAS.

[2] Dian, S. P., Erika, F. Analisis Pengendalian Persediaan Menggunakan Metode Probabilistik dengan Kebijakan Backorder dan Lost sales. Jurnal Teknik Industri. 2018; Vol. 19, No. 1. pp. 38-48

[3] Hadley G., Whitin, T.M. Analysis of Inventory Systems. Engle wood Cliffs, NJ : Prentice-Hall. 1963.

[4] Senator Nur Bahagia. Sistem Inventori. Penerbit ITB, Bandung, 2006.

[5] Silver, E.A., and Peterson, R., Decision Systems for Inventory Management and Production Planning, John Wiley Sons. New York, 1985.

[6] Tersine, R.J., Principles of Inventory and Materials Management, Printice-Hall Inc. New Jersey, 1994. 